\title{
GEOCHEMICAL EVOLUTION OF THE NYIRAGONGO VOLCANO (Virunga, Western African Rift, Zaire)
}

\author{
J. HERTOGEN; L. VANLERBERGHE and M. R. NAMEGABE
}

HERTOGEN, J; VANLERBERGHE, L. and NAMEGABE, M. R., 1985. Geochemical evolution of the Nyiragongo volcano (Virunga, Western African Rift, Zaire). Bull. Geol. Soc. Finland 57, Part 1-2, 21-35.

Strongly undersaturated foiditic lavas (nepheline-melilitites, nephelinites, leucitites) from the active Nyiragongo volcano have been analysed for trace elements (Sc, V, Cr, Co, Ba, REE, Hf, Ta, Th and U) by instrumental neutron activation analysis.

The overall low $\mathrm{Sc}$ and $\mathrm{Cr}$ contents and low $\mathrm{Mg} / \mathrm{Fe}$ ratios suggest that the Nyiragongo parent magma evolved from less undersaturated mantle magmas (olivine-nephelinitic, basanitic) by high-pressure pyroxene fractionation. Pyroxene fractionation seems to be the main cause of the pronounced petrological differences between the adjacent Nyiragongo and Nyamuragira volcanoes.

The distribution of incompatible trace elements within the melilite-nephelinitic magma column was strongly affected by migrating $\mathrm{CO}_{2}$-rich fluids. This is most clearly reflected in the unusually large fractionation of $U$ from $T h$ $(\mathrm{Th} / \mathrm{U}=4.5$ down to 0.15$)$, and the high and variable REE contents of the carbonated nepheline-melilitites (bergalites).

Major element differentiation within the magma column was dominated by melilite fractionation in the early stages. Later on, subtraction of pyroxene \pm magnetite) and flotation of leucite ( \pm nepheline) gave rise to the formation of highly foiditic porphyritic leucite-nephelinites and nepheline-leucitites.

Key words: volcanic rocks, geochemistry, trace elements, alkaline rocks, nephelinites, African Rift

J. Hertogen and L. Vanlerberghe: Afd. Fysico-chemische geologie, Leuven University, Celestijnenlaan 200C, B-3031 Leuven, Belgium.

M. R. Namegabe: Institute of Nuclear Sciences, Rijksuniversiteit Gent, B-9000 Gent, Belgium.

\section{Introduction}

The Nyiragongo volcano is located in the Virunga (or Birunga) area of the Western African Rift system. The Virunga field consists of eight major volcanoes (Fig. 1) and numerous satellitic eruption centres. None of these volcanoes ap- pears to be older than 2.5 Ma (Pouclet $1980 \mathrm{a}$ ), though there is mounting evidence for older Neogene volcanic series in the Virunga area (Kampunzu et al. 1983). These older series are probably related to the mildly tholeiitic and alkaline volcanism of the South Kivu field. The still active Nyiragongo and Nyamuragira are the 
youngest volcanoes (Upper Pleistocene, Recent). The Nyiragongo has long been famed for its semi-permanent lava lake.

The mineralogy and petrochemistry of the potassic and foiditic Virunga volcanics have been studied extensively since the pioneering work of Holmes and Harwood (1937). Results of earlier studies have been summarized by Bell and Powell (1969), Sahama (1978) and Pouclet (1980 a, b). Major element compositions and succinct petrographical descriptions of a large number of samples have been compiled by Denaeyer et al. (1965) and Denaeyer (1972).

The Nyiragongo lavas are quite distinct from those of the other Virunga volcanoes, including the adjacent Nyamuragira. Almost all Nyiragongo lavas are strongly undersaturated feldspar-free nepheline-melilitites and nephelinites; of the feldspathoids, leucite is generally far less abundant than nepheline (Sahama 1968, 1978). The primitive lavas from the other volcanoes are plagioclase-bearing, melilite-free basanites (s.l.), usually with leucite as the sole feldspathoid mineral. In many respects, the Nyiragongo rocks are intermediate between the main Virunga rock series and the ugandites, mafurites and katungites from the Toro-Ankole (Fig. 1) region (Bell and Powell 1969; Pouclet 1980 a, b).

Although the petrogenesis of alkaline undersaturated magmas is not yet fully understood, high-pressure experimental studies have shown they can be generated by small degrees of partial melting of mantle peridotite enriched in $\mathrm{H}_{2} \mathrm{O}$ and $\mathrm{CO}_{2}$ (e.g., Bultitude and Green 1967; Brey and Green 1975, 1977; Wyllie 1979; Edgar and Condliffe 1979). Crustal assimilation, often invoked in older petrogenetic models, is not necessary for the generation of potassic undersaturated magmas (see summary of older hypotheses in Bell and Powell, 1969). In any case, the uniform and relatively low ${ }^{87} \mathrm{Sr} /{ }^{86} \mathrm{Sr}$ isotopic ratios of the Nyiragongo lavas $(0.7045 \pm 10$ : Bell and Powell, 1969; 0.70457-0.70479: Vollmer and Norry, 1983) preclude any substantial crus-
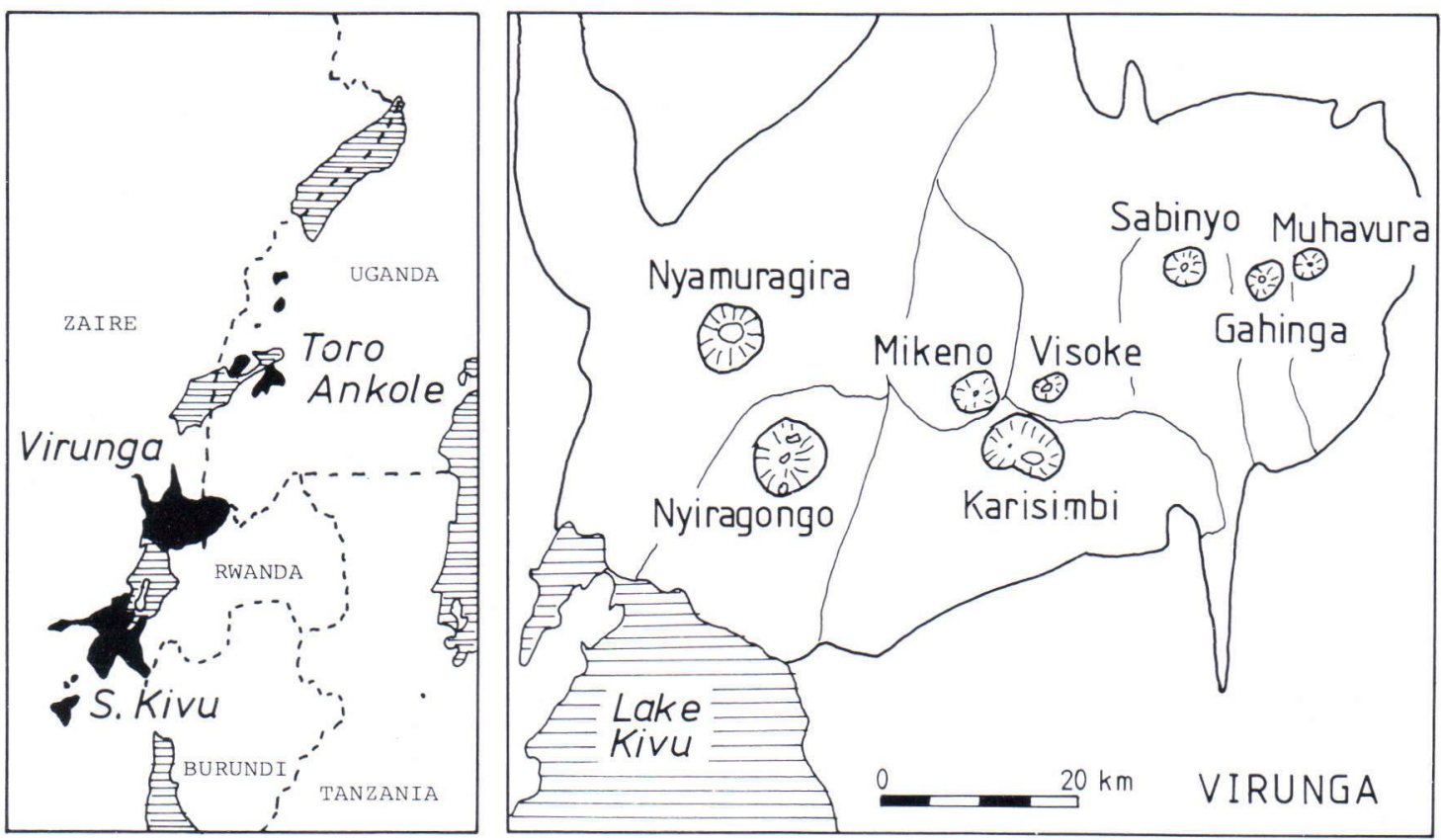

Fig. 1. (Left) Location of the three main volcanic fields within the Western African Rift System. Ruled areas are lakes. (Right) Distribution of the eight major volcanoes within the Virunga field. 
tal contamination.

To further constrain petrogenetic and magmatic evolution models for the Nyiragongo, we have analysed 46 well-documented samples for trace elements (Sc, V, Cr, Co, Ba, REE, Hf, $\mathrm{Ta}$, Th and U). This work supplements the less comprehensive trace element studies by Bell and Powell (1969) and Mitchell and Bell (1976). The two main objectives of the present study were: (i) to test the detailed magmatic evolution model proposed by Sahama $(1973,1978)$; (ii) to establish why the two active the Nyiragongo and the Nyamuragira volcanoes are characterized by different rock series.

\section{Samples and analytical method}

Most of the samples were collected during several Belgian and Finnish expeditions to the Nyiragongo in the fifties. Sample selection for this study was guided by the late Professor Th. G. Sahama. The sample locations are listed in Table 1. Samples from the inner main cone are well represented because the well defined lava stratigraphy makes it possible to trace the mag-
Table 1. Sample location. ${ }^{1}$

1. Inner main cone. ${ }^{2}$

- Inner Pit strata: LL59(MN. Lava lake 1959), VM706(MN), VM701(MN), VM511(MN), VM742(MN)

- Lava beds from inner walls of main cone: VM210(BE), VM269(BE), VM235(BE), VM569(BE), VM268(BE), VS216(MLN), VM574(LN).

- Dykes from inner walls of main cone: VM273(BE), VM234(BE), VM220(MLN), VM274(LN), VM213(LN), VM212(LN), VM241(LN).

2. Lavas from flanks of main cone. ${ }^{2}$ VM12(MLN), FEAE93(MLN), FEAE89(LN), S97(NL).

3. Shaheru satellite crater. VM394(MN).

4. Baruta satellite crater. S94(ON), S96(MN), S88(MN), VM362(MN), S90(LN).

5. Lava flows east of Goma-Rutshuru road. S55(ON), S59(ON), S69(OL), S68(MN), FEAE83(MN), S6(MN), S40(LN), S43(NL), S45(NL), FEAE85(NL), VM75(NL).

6. Lava flows west of Goma-Rutshuru road. S9b(OL), S75(MN), Dn54/101(MLN), S107(LN), S10(LN), S12(LN).

1 Reference is made to Denaeyer et al. (1965) and Denaeyer (1972) for further details of sample location, succinct petrographic description and major element composition. Rock nomenclature: $\mathrm{BE}=$ bergalite; $\mathrm{MN}=$ melilitenephelinite; $\mathrm{MLN}=$ melilite-leucite-nephelinite; $\mathrm{LN}=$ leucite-nephelinite; $\mathrm{NL}=$ nepheline-leucitite; $\mathrm{ON}=$ olivine-(melilite)-nephelinite; OL = olivine-leucitite.

2 Refers to pre-1972 configuration of the inner main cone (Sahama 1978).

Table 2. Major element composition of selected Nyiragongo samples.

\begin{tabular}{|c|c|c|c|c|c|c|c|c|c|c|}
\hline & S94 ${ }^{1}$ & S69 ${ }^{1}$ & VM2342 & VM269² & $\mathrm{S} 75^{2}$ & LL59 $^{2}$ & VM12 ${ }^{1}$ & FEAE $89^{2}$ & $\mathrm{~S} 45^{1}$ & $\mathrm{~S} 90^{1}$ \\
\hline $\mathrm{SiO}_{2}$ & 40.32 & 40.68 & 33.08 & 34.70 & 35.13 & 37.93 & 38.51 & 37.71 & 41.70 & 46.50 \\
\hline $\mathrm{TiO}_{2}$ & 3.00 & 3.71 & 2.64 & 2.42 & 2.83 & 2.71 & 3.71 & 2.24 & 3.44 & 1.75 \\
\hline $\mathrm{Al}_{2} \mathrm{O}_{3}$ & 13.09 & 11.97 & 11.31 & 12.98 & 13.04 & 15.87 & 13.82 & 17.99 & 15.45 & 19.00 \\
\hline $\mathrm{Fe}_{2} \mathrm{O}_{3}$ & 5.04 & 6.53 & 7.70 & 9.09 & 6.27 & 3.25 & 5.33 & 5.17 & 3.44 & 3.70 \\
\hline $\mathrm{FeO}$ & 6.92 & 6.64 & 5.52 & 3.02 & 6.68 & 9.79 & 8.21 & 5.93 & 8.55 & 4.18 \\
\hline $\mathrm{MnO}$ & 0.21 & 0.21 & 0.30 & 0.29 & 0.30 & 0.29 & 0.27 & 0.25 & 0.26 & 0.05 \\
\hline $\mathrm{MgO}$ & 8.72 & 8.43 & 7.29 & 5.52 & 6.50 & 4.52 & 5.07 & 4.14 & 4.70 & 2.73 \\
\hline $\mathrm{CaO}$ & 13.86 & 15.50 & 17.18 & 14.17 & 15.23 & 11.87 & 13.57 & 10.98 & 10.67 & 5.84 \\
\hline $\mathrm{Na}_{2} \mathrm{O}$ & 3.45 & 2.15 & 3.16 & 3.97 & 4.31 & 5.34 & 4.39 & 5.64 & 4.57 & 6.44 \\
\hline $\mathrm{K}_{2} \mathrm{O}$ & 3.22 & 2.75 & 3.60 & 4.86 & 4.75 & 5.68 & 4.29 & 6.28 & 4.79 & 8.75 \\
\hline $\mathrm{P}_{2} \mathrm{O}_{5}$ & 1.25 & 0.78 & 1.90 & 1.67 & 1.91 & 1.44 & 1.84 & 1.34 & 1.49 & 0.38 \\
\hline $\mathrm{H}_{2} \mathrm{O}+$ & 0.68 & 0.65 & 3.94 & 3.41 & 2.38 & 0.93 & 0.43 & 1.34 & 0.49 & 0.35 \\
\hline $\mathrm{H}_{2} \mathrm{O}-$ & 0.24 & 0.20 & & & & & 0.16 & & 0.17 & 0.12 \\
\hline $\mathrm{CO}_{2}$ & - & - & 1.98 & 3.16 & 0.40 & 0.11 & - & 0.48 & - & 0.15 \\
\hline Total & 100.00 & 100.20 & 99.60 & 99.26 & 99.73 & 99.73 & 99.60 & 99.49 & 99.72 & 99.94 \\
\hline Type $^{3}$ & $\mathrm{ON}$ & $\mathrm{OL}$ & $\mathrm{BE}$ & $\mathrm{BE}$ & MN & $\mathrm{MN}$ & MLN & LN & NL & LN \\
\hline
\end{tabular}

Ref.: ${ }^{1}$ Denaeyer et al. (1965), ${ }^{2}$ New analyses, Analyst: D. Coetermans, Leuven University, ${ }^{3}$ Rock type, see footnote in Table 1. 
Table 3. Trace element composition (ppm) of Nyiragongo lavas.

\begin{tabular}{|c|c|c|c|c|c|c|c|c|c|c|c|c|c|c|c|c|c|c|}
\hline & & Sc & $\mathrm{V}$ & $\mathrm{Cr}$ & $\mathrm{Co}$ & $\mathrm{Ba}$ & $\mathrm{La}$ & $\mathrm{Ce}$ & $\mathrm{Nd}$ & $\mathrm{Sm}$ & $\mathrm{Eu}$ & $\mathrm{Tb}$ & $\mathrm{Yb}$ & $\mathrm{Lu}$ & $\mathrm{Hf}$ & $\mathrm{Ta}$ & Th & $\mathrm{U}$ \\
\hline LL59 & $\mathrm{MN}$ & 3.9 & 209 & 7 & 44.5 & 2388 & 177 & 357 & 133 & 17.3 & 5.05 & 1.62 & 2.90 & 0.38 & 4.4 & 16.2 & 22.2 & 8.8 \\
\hline VM706 & $\mathrm{MN}$ & 4.6 & 273 & 46 & 44.2 & 2037 & 184 & 367 & 135 & 18.2 & 5.30 & 1.69 & 3.10 & 0.41 & 4.8 & 16.5 & 21.4 & 8.2 \\
\hline VM701 & $\mathrm{MN}$ & 3.6 & 247 & 52 & 39.4 & 1650 & 153 & 310 & 119 & 15.8 & 4.62 & 1.42 & 2.50 & 0.35 & 3.9 & 16.2 & 17.6 & 6.9 \\
\hline VM511 & $\mathrm{MN}$ & 4.6 & 235 & 7 & 35.6 & 1730 & 153 & 306 & 114 & 15.4 & 4.44 & 1.43 & 2.50 & 0.33 & 4.1 & 15.0 & 18.1 & 7.7 \\
\hline VM742 & $\mathrm{MN}$ & 4.4 & 278 & 8 & 42.2 & 1955 & 165 & 322 & 122 & 16.8 & 4.90 & 1.47 & 2.63 & 0.38 & 4.5 & 15.5 & 18.7 & 7.3 \\
\hline VM210 & $\mathrm{BE}$ & 8.7 & & 10 & 40.8 & 3211 & 264 & 504 & 183 & 24.8 & 7.27 & 2.38 & 4.30 & 0.66 & 6.7 & 27.6 & 36.3 & 22. \\
\hline VM269 & BE & 7.8 & 350 & 11 & 37.0 & 2089 & 214 & 413 & 151 & 21.2 & 5.86 & 1.84 & 3.34 & 0.49 & 5.3 & 21.7 & 28.6 & 12.4 \\
\hline VM235 & $\mathrm{BE}$ & 7.9 & & 10 & 38.5 & 6400 & 265 & 498 & 173 & 22.5 & 7.13 & 2.40 & 4.11 & 0.59 & 5.9 & 26.9 & 35.0 & 238. \\
\hline VM569 & $\mathrm{BE}$ & 6.6 & 484 & 9 & 41.4 & 2164 & 239 & 470 & 175 & 23.9 & 6.76 & 2.06 & 3.54 & 0.49 & 5.2 & 23.9 & 28.7 & 12.6 \\
\hline VM268 & $\mathrm{BE}$ & 15.5 & 335 & 157 & 40.2 & 1697 & 177 & 336 & 141 & 18.4 & 5.07 & 1.58 & 2.86 & 0.39 & 5.6 & 15.6 & 20.6 & 10.7 \\
\hline VS216 & MLN & 5.2 & & 8 & 46.7 & 1604 & 145 & 286 & 114 & 15.6 & 4.44 & 1.43 & 2.34 & 0.43 & 4.8 & 12.1 & 14.7 & $\quad 4.0$ \\
\hline VM574 & LN & 1.8 & 169 & 60 & 33.2 & 1793 & 139 & 273 & 97 & 13.4 & 3.89 & 1.14 & 2.26 & 0.33 & 3.6 & 15.2 & 17.1 & 3.8 \\
\hline VM273 & $\mathrm{BE}$ & 6.4 & 320 & 16 & 39.3 & 2385 & 235 & 449 & 163 & 21.6 & 6.17 & 2.01 & 3.68 & 0.47 & 5.3 & 20.4 & 30.0 & 18.2 \\
\hline VM234 & $\mathrm{BE}$ & 9.6 & 401 & 28 & 43.3 & 1740 & 194 & 384 & 144 & 19.9 & 5.71 & 1.75 & 3.08 & 0.40 & 5.0 & 19.5 & 23.6 & 12.3 \\
\hline VM220 & MLN & 2.3 & 161 & $\leqslant 2$ & 27.1 & 1782 & 136 & 268 & 101 & 13.2 & 3.89 & 1.21 & 2.41 & 0.33 & 3.2 & 14.2 & 16.1 & 5.6 \\
\hline VM274 & LN & 5.1 & 204 & 11 & 36.6 & 2207 & 181 & 336 & 112 & 14.6 & 4.30 & 1.30 & 2.86 & 0.42 & 4.8 & 16.4 & 27.6 & 6.5 \\
\hline VM213 & LN & 5.1 & 206 & 9 & 29.5 & 2139 & 172 & 325 & 115 & 14.2 & 4.13 & 1.23 & 2.69 & 0.36 & 4.5 & 16.1 & 24.5 & 16.5 \\
\hline VM212 & LN & 1.50 & & 8 & 17.2 & 3755 & 209 & 361 & 112 & 13.7 & 4.01 & 1.33 & 2.90 & 0.49 & 4.6 & 23.6 & 37.9 & 12.3 \\
\hline VM241 & $\mathrm{LN}$ & 1.25 & & 7 & 14.3 & 3300 & 179 & 312 & 91 & 11.4 & 3.41 & 1.14 & 2.58 & 0.37 & 3.8 & 20.9 & 34.0 & 20. \\
\hline VM12 & MLN & 7.1 & & 8 & 50.9 & 2380 & 151 & 308 & 127 & 17.8 & 5.19 & 1.67 & 2.68 & 0.44 & 5.9 & 12.8 & 15.2 & 8.0 \\
\hline FEAE93 & MLN & 2.9 & 207 & 4 & 35.8 & 2133 & 161 & 324 & 119 & 16.4 & 4.73 & 1.46 & 2.80 & 0.41 & 4.3 & 16.4 & 18.8 & 6.7 \\
\hline FEAE89 & $\mathrm{LN}$ & 3.2 & 285 & 7 & 36.5 & 1584 & 166 & 322 & 115 & 15.6 & 4.33 & 1.32 & 2.60 & 0.36 & 3.5 & 16.6 & 22.0 & 8.7 \\
\hline S97 & NL & 1.32 & & 8 & 14.8 & 3163 & 184 & 325 & 95 & 11.8 & 3.52 & 1.13 & 2.54 & 0.43 & 4.2 & 20.9 & 33.9 & 7.9 \\
\hline VM394 & $\mathrm{MN}$ & 12.9 & & $\leqslant 3$ & 38.1 & 3223 & 265 & 514 & 191 & 26.8 & 7.80 & 2.59 & 4.45 & 0.79 & 7.4 & 25.9 & 32.6 & 14.4 \\
\hline S94 & ON & 20.9 & & 365 & 50.0 & 1316 & 128 & 255 & 100 & 14.2 & 4.19 & 1.38 & 2.53 & 0.40 & 6.2 & 11.0 & 15.0 & 5.5 \\
\hline S96 & $\mathrm{MN}$ & 10.9 & & 71 & 44.5 & 1989 & 192 & 379 & 146 & 19.6 & 5.72 & 1.80 & 2.82 & 0.46 & 5.0 & 18.1 & 19.9 & 9.4 \\
\hline S88 & $\mathrm{MN}$ & 3.6 & & 3 & 41.8 & 1787 & 157 & 309 & 118 & 15.9 & 4.59 & 1.53 & 2.48 & 0.37 & 3.3 & 15.8 & 18.1 & 7.3 \\
\hline VM362 & $\mathrm{MN}$ & 9.3 & & 37 & 41.9 & 2260 & 201 & 371 & 138 & 19.0 & 5.69 & 1.87 & 3.41 & 0.54 & 5.7 & 18.9 & 17.3 & 11.5 \\
\hline S90 & $\mathrm{LN}$ & 1.43 & & $\leqslant 2$ & 17.3 & 2304 & 148 & 262 & 85 & 10.5 & 3.12 & 1.01 & 2.28 & 0.42 & 3.4 & 15.0 & 23.9 & 9.6 \\
\hline S55 & $\mathrm{ON}$ & 12.2 & & 68 & 51.5 & 1243 & 122 & $240^{\circ}$ & 101 & 14.8 & 4.30 & 1.42 & 2.42 & 0.44 & 6.0 & 10.2 & 13.6 & 3.9 \\
\hline S59 & $\mathrm{ON}$ & 29.8 & & 268 & 49.0 & 1050 & 109 & 222 & 94 & 13.9 & 4.07 & 1.31 & 2.08 & 0.36 & 7.2 & 9.4 & 12.1 & 4.3 \\
\hline S69 & $\mathrm{OL}$ & 33.4 & & 166 & 53.3 & 1070 & 80 & 168 & 74 & 11.5 & 3.33 & 1.13 & 1.94 & 0.31 & 7.1 & 8.8 & 9.0 & 2.2 \\
\hline S68 & $\mathrm{MN}$ & 9.2 & 386 & 12 & 36.0 & 1930 & 208 & 413 & 159 & 22.2 & 6.12 & 1.98 & 3.57 & 0.49 & 6.2 & 21.5 & 25.5 & 19. \\
\hline FEAE83 & $\mathrm{MN}$ & 4.4 & & 16 & 41.9 & 2032 & 206 & 426 & 158 & 21.3 & 6.10 & 1.89 & 3.28 & 0.49 & 4.0 & 23.6 & 27.4 & 11.0 \\
\hline S6 & $\mathrm{MN}$ & 5.0 & & 9 & 45.6 & 2414 & 173 & 343 & 131 & 17.6 & 5.11 & 1.67 & 2.91 & 0.45 & 4.7 & 16.2 & 18.9 & 7.1 \\
\hline S40 & $\mathrm{LN}$ & 4.5 & & $\leqslant 4$ & 46.3 & 2140 & 171 & 345 & 134 & 17.8 & 5.27 & 1.70 & 2.97 & 0.46 & 5.3 & 15.8 & 19.5 & 5.9 \\
\hline S43 & NL & 3.5 & & 11 & 42.6 & 2002 & 146 & 294 & 115 & 16.0 & 4.62 & 1.52 & 2.56 & 0.45 & 4.6 & 13.2 & 16.0 & 5.4 \\
\hline S45 & NL & 9.3 & & 28 & 42.0 & 2470 & 142 & 274 & 104 & 14.3 & 4.21 & 1.39 & 2.48 & 0.39 & 6.2 & 14.1 & 19.3 & 5.5 \\
\hline FEAE85 & NL & 5.8 & 209 & 18 & 34.1 & 1502 & 120 & 234 & 88 & 12.1 & 3.43 & 1.04 & 2.14 & 0.31 & 5.0 & 12.2 & 16.7 & 5.0 \\
\hline VM75 & NL & 4.8 & 202 & 15 & 36.7 & 1797 & 141 & 269 & 99 & 13.6 & 3.97 & 1.20 & 2.40 & 0.35 & 4.5 & 15.5 & 19.8 & 5.7 \\
\hline S9b & $\mathrm{OL}$ & 18.1 & & 265 & 47.6 & 1473 & 114 & 227 & 92 & 13.6 & 3.88 & 1.33 & 2.28 & 0.37 & 6.5 & 12.9 & 14.0 & 5.2 \\
\hline S75 & $\mathrm{MN}$ & 7.4 & 385 & 25 & 42.5 & 1932 & 196 & 390 & 152 & 20.6 & 5.98 & 1.86 & 3.16 & 0.42 & 4.9 & 16.5 & 22.0 & 9.6 \\
\hline DN54101 & MLN & 4.3 & 295 & 11 & 44.2 & 1972 & 169 & 338 & 135 & 17.7 & 5.09 & 1.57 & 2.85 & 0.41 & 4.8 & 14.3 & 18.0 & 4.7 \\
\hline S107 & LN & 4.2 & & 4 & 42.8 & 2090 & 164 & 319 & 123 & 16.8 & 4.87 & 1.56 & 2.70 & 0.46 & 4.9 & 14.7 & 18.7 & 5.6 \\
\hline $\mathrm{S} 10$ & $\mathrm{LN}$ & 4.4 & & $\leqslant 3$ & 45.0 & 2154 & 169 & 339 & 131 & 17.7 & 5.20 & 1.68 & 2.97 & 0.49 & 5.3 & 15.9 & 20.0 & 6.8 \\
\hline $\mathrm{S} 12$ & $\mathrm{LN}$ & 4.4 & & $\leqslant 3$ & 44.2 & 2188 & 169 & 339 & 130 & 17.7 & 5.18 & 1.74 & 3.02 & 0.48 & 5.4 & 16.0 & 19.6 & 6.5 \\
\hline
\end{tabular}


matic evolution in time. The lavas from the 1972 and 1977 eruptions have not been studied, but one may assume that they are not too different from the lava-lake material sampled in 1959 (sample LL59).

The nomenclature of the Virunga rocks has long been complicated by the use of local and inappropriate names. The rock terminology adopted in the present paper is based on the simplified and revised classification proposed by Sahama (1978) and Pouclet (1980 a, b). Rock names and abbreviations are listed in Table 1. As recommended by Sahama (1978), the name bergalite has been retained for the calcite-rich and olivine-poor Nyiragongo nepheline-melilitites. The olivine-nephelinites and olivine- leucitites are not common lava types and are mainly associated with old, secondary eruption centres.

The trace elements were determined by instrumental neutron activation analysis. The induced gamma-ray activities were measured with large $\mathrm{Ge}(\mathrm{Li})$ detectors and small high-resolution low-energy photon detectors (Hertogen and Gijbels 1971). Samples (800 mg for whole rocks, $150 \mathrm{mg}$ for mineral separates) were irradiated for seven hours at a neutron flux of ca. $2.10^{12} \mathrm{n} . \mathrm{cm}^{-2} \cdot \mathrm{sec}^{-1}$ in the Thetis reactor of the Institute of Nuclear Sciences, Rijksuniversiteit Gent. Vanadium was determined via ${ }^{52} \mathrm{~V}$ $\left(\mathrm{T}_{1 / 2}=3.8 \mathrm{~min}\right)$ after five minutes irradiation. The samples were analysed relative to a second-

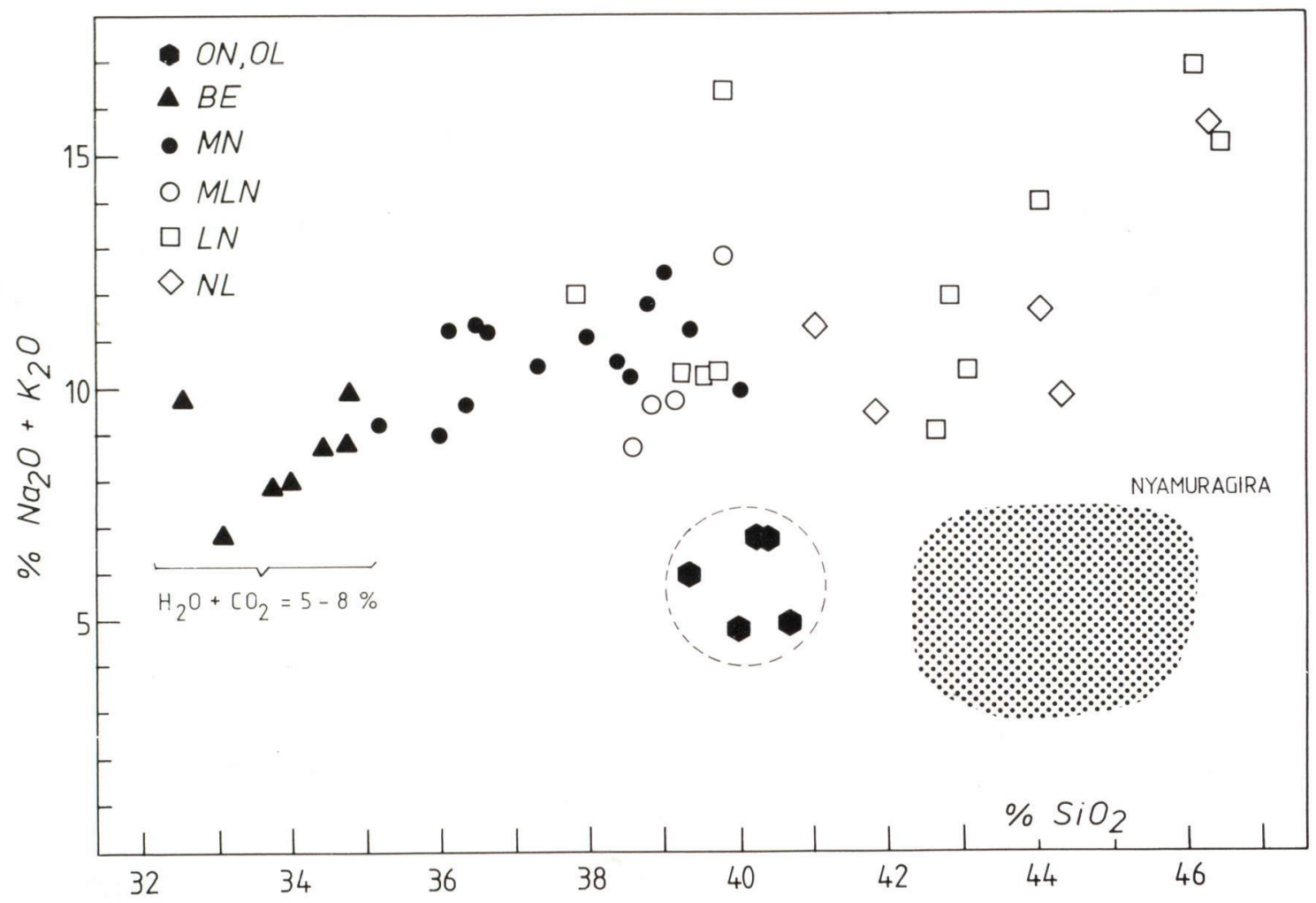

Fig. 2. Alkali and silica content of Nyiragongo samples studied in this work. See text and Table 1 for rock nomenclature and abbreviations. Almost all lavas from the adjacent Nyamuragira volcano plot within the dotted area (Pouclet 1980 a). The Nyiragongo and Nyamuragira are characterized by distinctly different rock series. However, the olivine-nephelinites and olivine-leucitites (circled) fall off the main Nyiragongo trend. In most respects (see also Figs. 3, 5-7) they are intermediate between the Nyamuragira lavas and the most undersaturated Nyiragongo lavas (bergalites, melilite-nephelinites). 
ary in-house alkali basalt standard that had been repeatedly calibrated against international reference rocks.

\section{Main chemical fractionation trends}

The major element geochemistry of the Nyiragongo rocks has been discussed at length elsewhere (Sahama 1973, 1980; Pouclet 1980 a, b; Pouclet et al. 1983) and will not be exhaustively treated in this paper. For ease of reference, the compositions of 10 representative samples are presented in Table 2 . Table 3 shows the trace element data for all the samples analysed in the present study.

The compositional differences between the Nyiragongo and Nyamuragira lavas are well illustrated by the $\mathrm{Na}_{2} \mathrm{O}+\mathrm{K}_{2} \mathrm{O}$ versus $\mathrm{SiO}_{2}$ diagram (Fig. 2). The Nyiragongo rocks are highly alkaline with $\mathrm{K}_{2} \mathrm{O} / \mathrm{Na}_{2} \mathrm{O}=1$. The melilite-bearing rocks in particular are strongly undersaturated and the most undersaturated bergalites have rather high $\mathrm{H}_{2} \mathrm{O}$ and $\mathrm{CO}_{2}$ contents. The $\mathrm{CO}_{2}$ derives mainly from calcite in the groundmass. Only leucite-rich rocks have more than $41 \% \mathrm{SiO}_{2}$.

Attention is drawn to the position of the

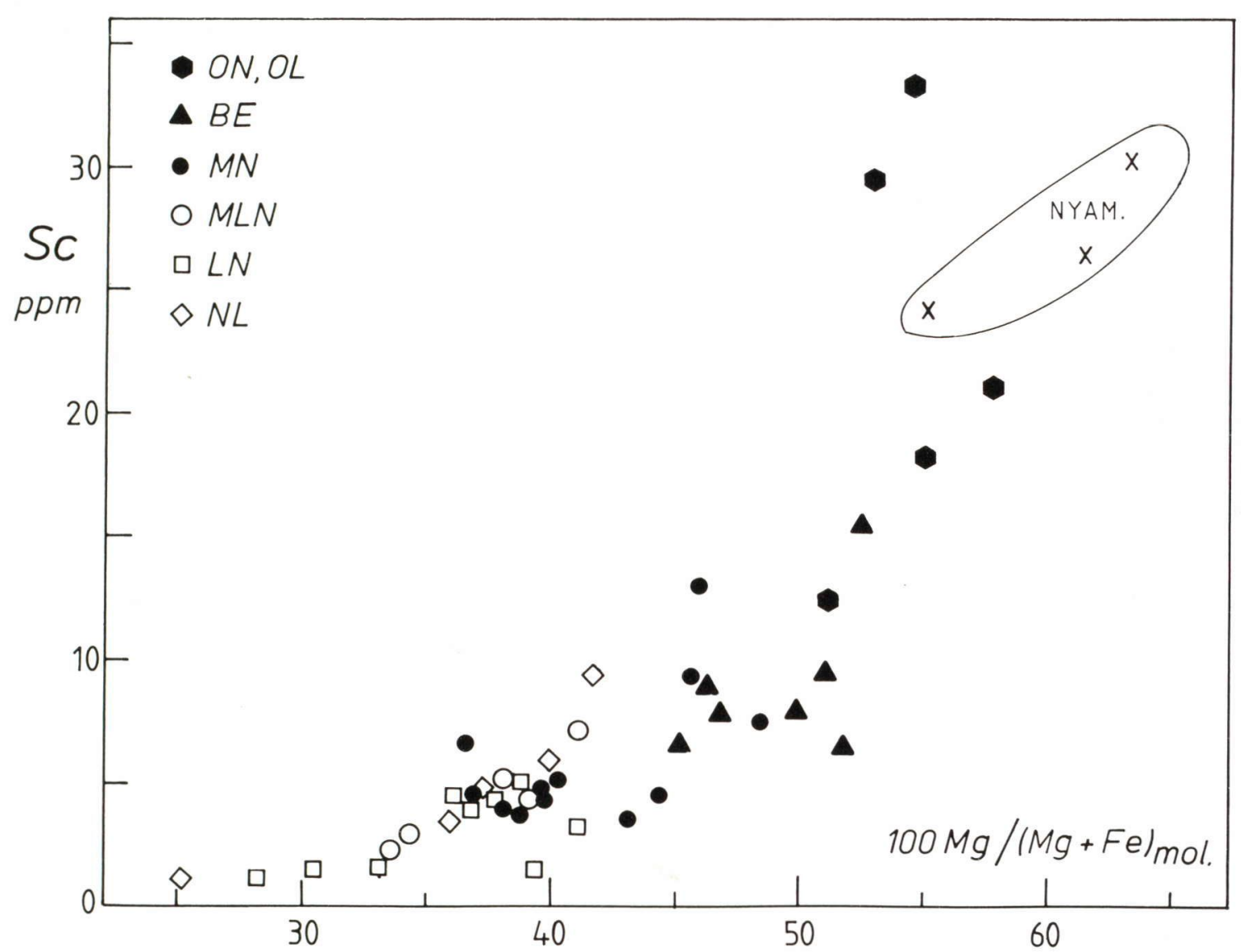

Fig. 3. Variation in $\mathrm{Sc}$ content and $\mathrm{Mg} /(\mathrm{Mg}+\mathrm{Fe})$ molar ratio in the Nyiragongo lavas. Total iron was used because the $\mathrm{Fe}^{3+} / \mathrm{Fe}^{2+}$ ratios are extremely variable and affected by secondary oxidation. Most of the Nyiragongo samples are moderately to strongly fractionated. The low Sc contents point to important pyroxene \pm garnet fractionation. Crosses are three primitive anakaratrites from the Nyamuragira (Smet 1980). 
olivine-(melilite)-nephelinites and olivine-leucitites in Fig. 2. These rocks deviate from the main Nyiragongo trend and are closer in composition to the least evolved Nyamuragira anakaratrites, basanites and limburgites. In almost all respects the olivine-nephelinites and olivine-leucitites fill the compositional gaps between the Nyiragongo and Nyamuragira lavas (Figs. 2, 6, 7). It is obvious that they provide some sort of a petrogenetic link between the two adjacent volcanoes.

It must be emphasized that, apart from the olivine-nephelinites and leucitites-, the Nyiragongo rocks are moderately to strongly fractionated, as evidenced by the low $\mathrm{Mg} /(\mathrm{Mg}+\mathrm{Fe})$ ratios (Fig. 3) and low Sc (Fig. 3) and $\mathrm{Cr}$ (Table 3) concentrations. The low Sc contents impose

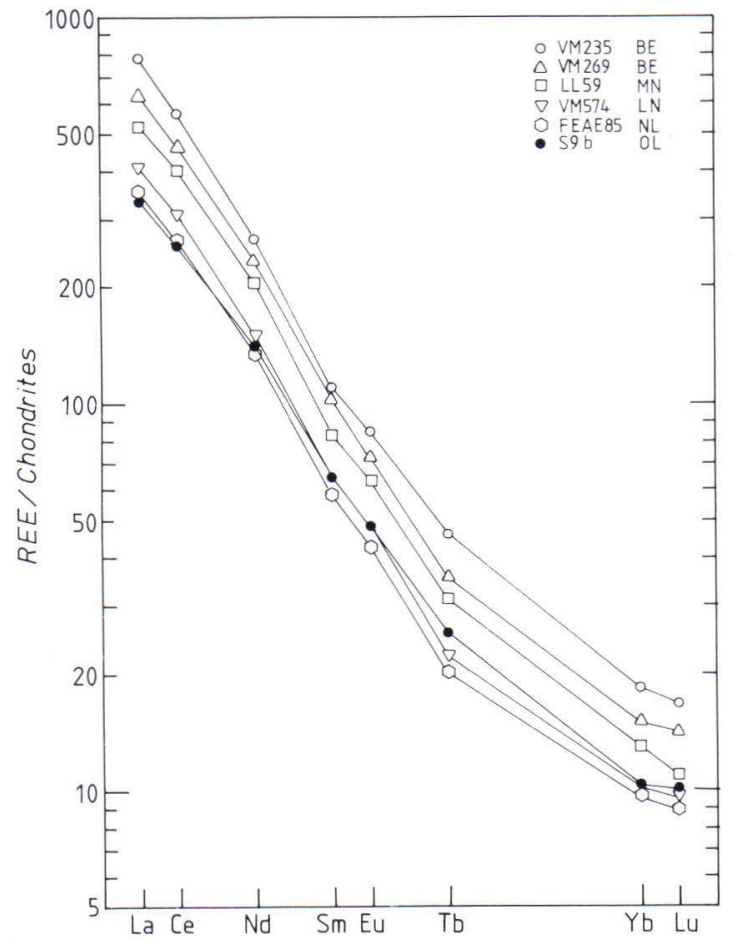

Fig. 4. Chondrite-normalized REE patterns of selected Nyiragongo lavas. Bergalite VM235 has the highest and nepheline-leucitite FEAE85 the lowest REE abundances of all samples analysed. Note that the patterns of the Nyiragongo samples are virtually parallel. important constraints on petrogenetic models for the Nyiragongo. They indicate extensive fractionation involving clinocpyroxene or garnet, or both. However, the rather limited fractionation of heavy from light rare earth elements (Figs. 4-6) rules out the importance of garnet fractionation. (See section on crystal fractionation below and papers by Irving (1978) and Irving and Frey (1978) for crystal/liquid partition coefficient data.)

Like almost all undersaturated alkaline rocks, the Nyiragongo lavas are characterized by high concentrations of the incompatible lithophile trace elements $\mathrm{Rb}, \mathrm{Sr}, \mathrm{Zr}, \mathrm{Nb}, \mathrm{Ba}$, light REE, Hf, Ta, Th and U (this work; Bell and Powell 1969; Mitchell and Bell 1976). Enrichment of light over heavy REE in the Nyira-

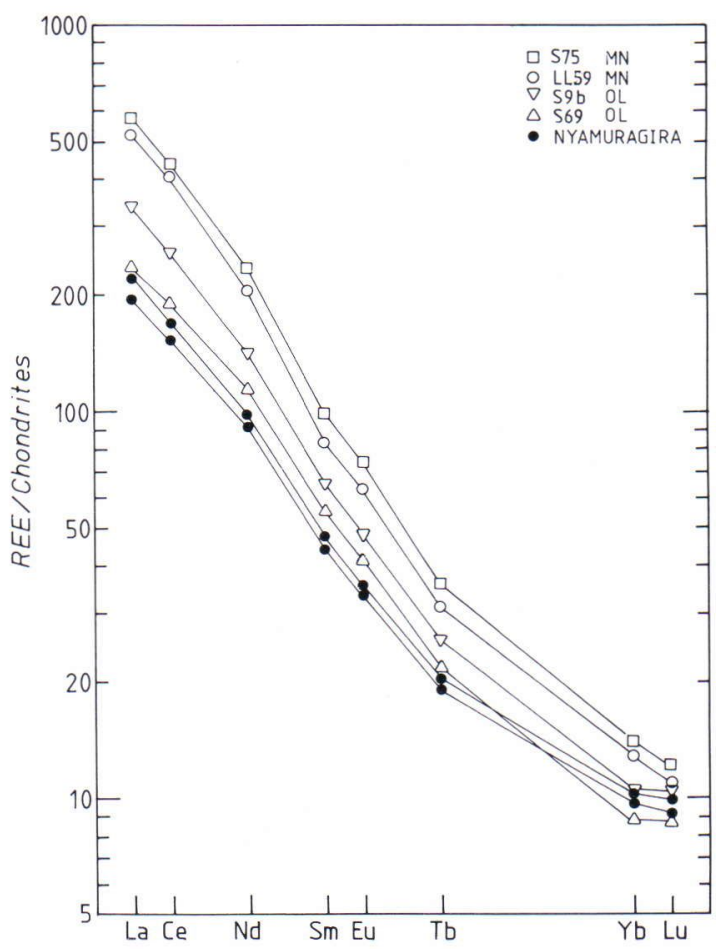

Fig. 5. Chondrite-normalized REE patterns of selected Nyiragongo lavas (this work) and Nyamuragira ankaratrites (Smet 1980). Note the similarity between Nyamuragira lavas and the Nyiragongo olivine-leucitites. 
gongo lavas is more pronounced than in lavas from the other Virunga volcanics (Mitchell and Bell 1976; Smet 1980), though the chondritenormalized $\mathrm{La} / \mathrm{Yb}$ ratios (30-45; Fig. 6) are much lower than those observed in the rocks from the Toro-Ankole region $\left(\mathrm{La} / \mathrm{Yb}_{\mathrm{N}}=80-\right.$ 200; Mitchell and Bell 1976).

Two conspicuous features of the REE geochemistry of the Nyiragongo lavas need to be stressed and should be accounted for by any viable magmatic evolution model. First, the ma-

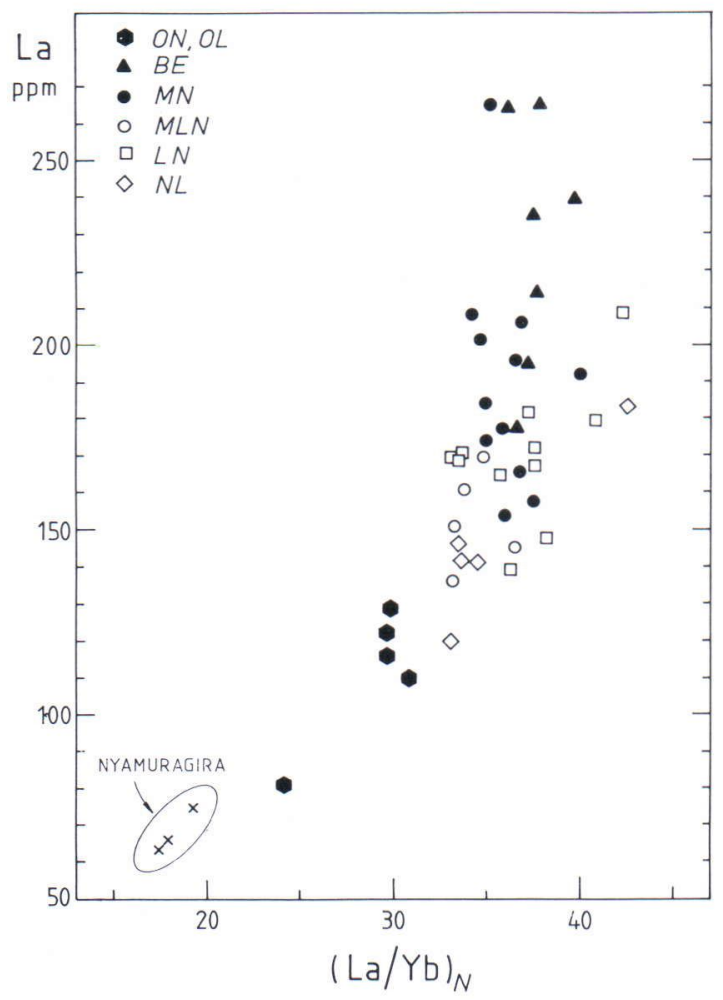

Fig. 6. Summary of REE systematics of the Nyiragongo samples. La/Yb ratios are chondrite-normalized. Four aspects of the data should be emphasized: (1) La/Yb ratios within the main Nyiragongo series are rather constant in spite of large variations in absolute REE abundances; (2) absolute REE contents tend to decrease with increasing $\mathrm{SiO}_{2}$ contents (compare with Fig. 2); (3) absolute REE abundances of the bergalites are very variable, though bergalites have very similar major element compositions; (4) the olivine-nephelinites and olivine-leucitites bridge the gap between the Nyamuragira lavas and the Nyiragongo main series. jority of the lavas have virtually parallel REE patterns in spite of the large differences in absolute REE abundances and in degree of differentiation (Figs. 3-6). Second, the concentration of REE and other incompatible trace elements tends to decrease with increasing $\mathrm{K}_{2} \mathrm{O}$ content and increasing degree of differentiation (Figs. 3 and 7). Hence the potassium enrichment cannot simply be ascribed to crystallization of a K-poor mafic mineral phase, as this would lead to concomitant enrichment of incompatible elements.

An amazing result of the present study is the evidence for an unusually large fractionation of $\mathrm{U}$ from Th (Fig. 8). We shall argue below that the $\mathrm{Th} / \mathrm{U}$ fractionation and the REE distribution in the bergalites is strong evidence for fluid fractionation in the Nyiragongo magma column.

\section{The nature of the parental magma}

Two alternative petrogenetic models are proposed as explanations of the strongly undersaturated character of the Nyiragongo rocks:

1. The majority of the magmas derive from a primary melilite-nephelinitic or nepheline-melilititic parental magma formed by minor partial melting of mantle peridotite enriched in $\mathrm{H}_{2} \mathrm{O}$ and $\mathrm{CO}_{2}$ (e.g. Brey and Green 1975, 1977). The occurrence of less undersaturated olivine-nephelinites and olivine-leucitites, and the differences between the Nyiragongo and Nyamuragira magmas in general could then be interpreted in terms of different degrees of melting or variable amounts of $\mathrm{H}_{2} \mathrm{O}$ and $\mathrm{CO}_{2}$ in the respective source regions (e.g., Frey et al. 1978).

2. The Nyiragongo and Nyamuragira volcanoes evolved from very similar 'basanitic' (s.l.) parental magmas. However, the parental magmas underwent a different fractionation history, which in the case of Nyiragongo led to increasing silica-undersaturation and enrichment of alkalies, incompatible trace elements and volatiles. This model has the advantage over the first one that it accounts naturally for the ap- 
parent absence of really primitive magmas from the most undersaturated Nyiragongo lavas (Fig. 3).

We shall now argue that the second model is the more plausible one in the light of experimental studies on high-pressure liquidus phase relations in undersaturated magmas in the presence of $\mathrm{H}_{2} \mathrm{O}$ and $\mathrm{CO}_{2}$ (olivine-nephelinites: Bultitude and Green 1967; olivine-melilitite: Brey and Green 1975, 1977). These studies showed that aluminous pyroxenes are the major near-liquidus phases at pressures above ca. 20 kbar. Upon fractionation of pyroxenes ( \pm garnet) a Nyamuragira-type primitive magma would differentiate towards strongly undersaturated alkaline compositions characterized by relatively low $\mathrm{Mg} /(\mathrm{Mg}+\mathrm{Fe})$ ratios and low $\mathrm{Sc}$ and $\mathrm{Cr}$ contents, as is indeed observed for the Nyiragongo bergalites and melilite-nephelinites (Fig. 3; Table 3). In any case, the low Sc contents of Nyiragongo lavas point to the important role of pyroxene \pm garnet fractionation, because only these two phases have high $(>2)$ crystal/liquid partition coefficients for Sc (Irving 1978; Irving and Frey 1978).

The pyroxene fractionation model has been tested with major element least-squares mass balance calculations, using a computer program based on the mathematical model developed by Stormer and Nicholls (1978). The pyroxene and garnet compositions were taken from Bultitude and Green (1967) and Brey and Green (1977). The differentiation from olivine-nephelinites and olivine-leucitites to bergalites and melilitenephelinites could be modelled quite satisfactorily by fractionation of $25-35 \%$ clinopyroxene plus $3-6 \%$ orthopyroxene. The smallest residuals were generally obtained when using the pyroxene compositions of Bultitude and Green (1967). This appears reasonable because the average composition of the magma was closer to that of nephelinites than melilitites during this fractionation stage. Given the sensitivity of the calculations to changes in the pyroxene compositions, it must be admitted that the relative proportions of clinopyroxene and orthopyroxene are not rigidly constrained. Inclusion of garnet in the calculations did not consistently improve the results. Nevertheless, the increase in the $\mathrm{La} / \mathrm{Yb}$ ratio during differentiation from olivine-nephelinites to bergalites and melilite-nephelinites (Fig. 6) appears somewhat too large to be explained by 30 to $40 \%$ pyroxene fractionation alone. Fractionation of relatively small amounts of garnet, characterized by high heavy REE partition coefficients (Irving and Frey 1978) might be required to remedy this problem.

It is obvious that $30-40 \%$ pyroxene fractionation only partly accounts for the high REE contents observed in some bergalites and melilitenephelinites (Figs. 4-6). In the next section we shall present evidence that these high abundances of REE and other incompatible trace elements are due to fluid fractionation in the Nyiragongo magma column.

With the data available it is not possible to establish whether the olivine-nephelinites represent the Nyiragongo primary magma or whether they in turn evolved from a basanitic magma by pyroxene subtraction. The extent of prior pyroxene fractionation seems to be limited by the high $\mathrm{Cr}$ (>350 ppm) and Sc (>30 ppm) contents of some olivine-nephelinites. This could imply that the parental magma of the Nyiragongo and Nyamuragira volcanoes is not exactly the same.

Sahama $(1973,1978)$ and Pouclet (1980 a) have suggested that the Nyiragongo and Nyamuragira lavas might ultimately derive from very similar parental magmas. Our analysis of the data support this view, though we invoke different differentiation processes. Sahama attributed the difference in chemistry between the two volcanoes to the concentration of an alkali-rich, carbonated fluid phase in the Nyiragongo magma. This model partially accounts for the low $\mathrm{SiO}_{2}$ contents - merely the result of passive $\mathrm{SiO}_{2}$ depletion - but leaves the $\mathrm{Mg} / \mathrm{Fe}, \mathrm{Sc}$ and $\mathrm{Cr}$ fractionation unexplained. We shall argue below 
that fluid fractionation did indeed occur in the Nyiragongo magma column. However, the fluid phase was probably not strongly alkaline, as the $\mathrm{H}_{2} \mathrm{O}+\mathrm{CO}_{2}$ rich bergalites generally have lower $\mathrm{Na}_{2} \mathrm{O}$ and $\mathrm{K}_{2} \mathrm{O}$ contents than the volatile-poor melilite-nephelinites (Fig. 2).

\section{Crystal and fluid fractionation in the Nyiragongo magma column}

The lava stratigraphy inside the Nyiragongo main cone offers valuable clues to the magmatic evolution during the main eruptive phases of this volcano (Tazieff 1966; Sahama 1978). The oldest exposed strata are made up of bergalites cut by dykes and covered with lavas of (melilite)leucite-nephelinitic and nepheline-leucititic

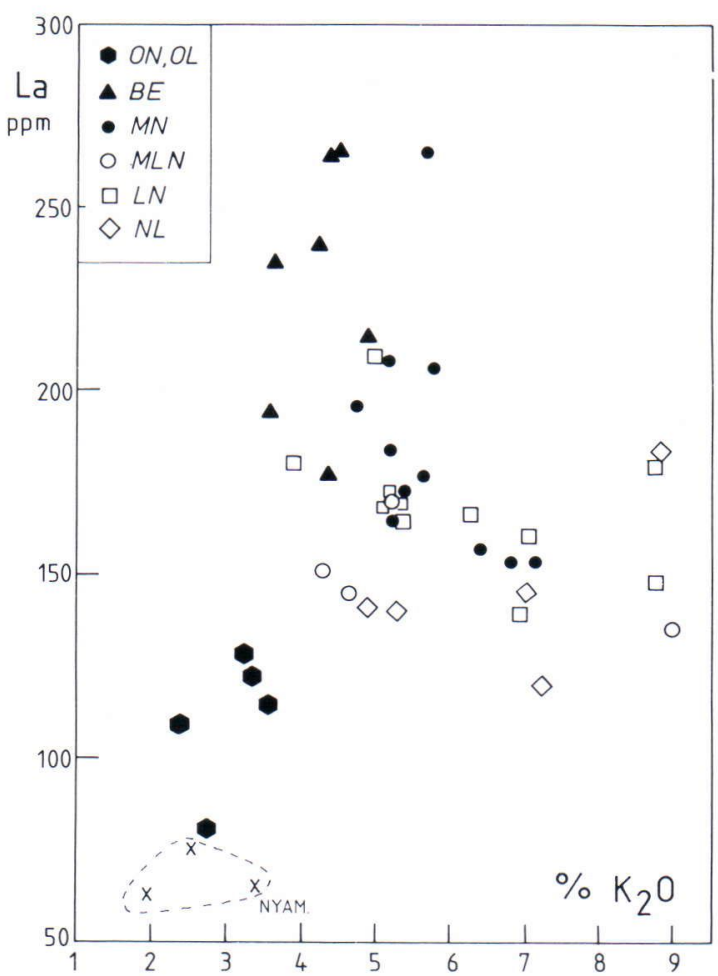

Fig. 7. La and $\mathrm{K}$ contents of the Nyiragongo lavas. REE abundances tend to decrease with increasing $\mathrm{K}_{2} \mathrm{O}$ contents owing to flotation of leucite and nepheline. composition. Because the younger lavas in this sequence are the most fractionated ones (Figs. 2 and 3), the magmatic evolution of the Nyiragongo can possibly be largely interpreted in terms of fractionation of a bergalitic or melilitenephelinitic parent magma. This parent magma itself derived from a primary olivine-nephelinitic or basanitic magma, as argued in the preceding section.

Note that the most recent lavas from the inner pit and lava lake (Table 1) are less differentiated than the older leucite-nephelinites and nepheline-leucitites. This might imply that the magma chamber or the top of the magma column beneath the Nyiragongo has been replenished at least once with less fractionated magma.

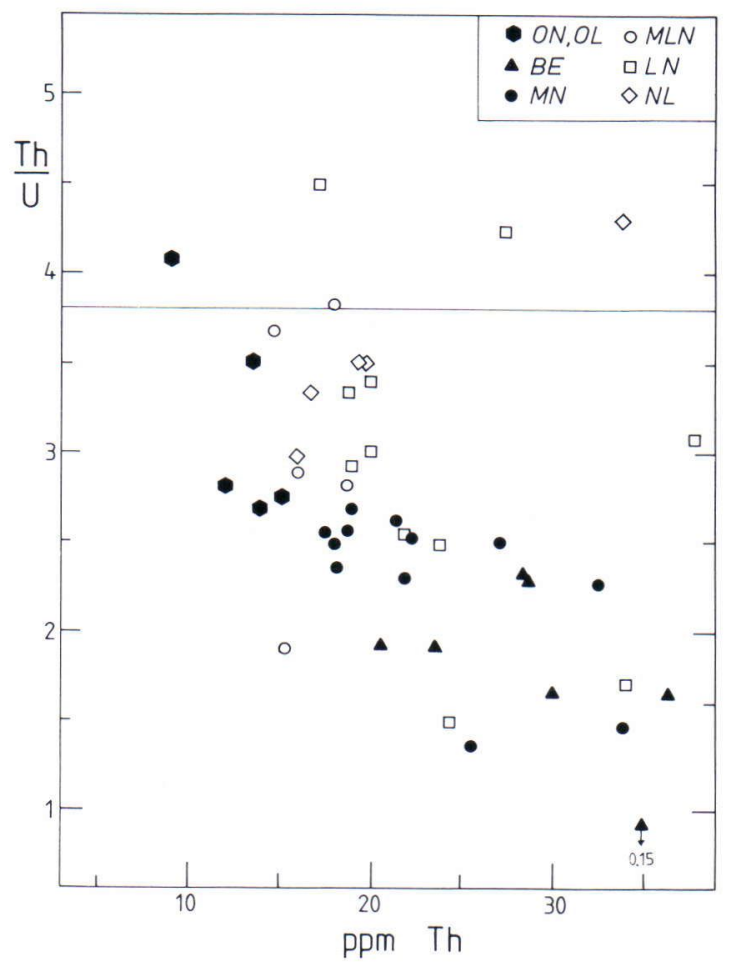

Fig. 8. Fractionation of $U$ from $T h$ in the Nyiragongo lavas is unusually large, and is hard to explain by simple crystal fractionation. The uranium enrichment is attributed to fluid fractionation in the magma column. The horizontal line drawn at $\mathrm{Th} / \mathrm{U}=3.8$ represents the commonly accepted value for primitive mantle. 
Before evaluating the crystal fractionation models we should asses the role of fluids. Consideration of fluid fractionation is prompted by the high $\mathrm{H}_{2} \mathrm{O}$ and $\mathrm{CO}_{2}$ contents of the bergalites (Fig. 2), and especially by the unusually large $\mathrm{Th} / \mathrm{U}$ fractionation (Fig. 8). Since none of the major phenocryst phases of the Nyiragongo lavas selectively concentrates either $\mathrm{Th}$ or $\mathrm{U}$ (Table 4), the $\mathrm{Th} / \mathrm{U}$ fractionation is hard to explain by crystal fractionation. A far more plausible explanation is very strong partitioning of uranium into a fluid phase as a result of formation of stable chloride, fluoride, and carbonate complexes (Langmuir 1978). In any case, the $\mathrm{Th} / \mathrm{U}$ fractionation must be attributed to $\mathrm{ab}-$ normal behaviour of $U$, because the ratios of Th to other incompatible trace elements such as $\mathrm{La}$ and Ta are within the ranges typical of alkaline basic rocks $(\mathrm{La} / \mathrm{Th}=6-10 ; \mathrm{Th} / \mathrm{Ta}=$ 1-1.5; Wood et al. 1979).

Fluid fractionation also makes it easier for us to understand why the concentrations of incompatible trace elements (REE, Hf, Ta, Th, U) correlate rather poorly with the major element composition and degree of fractionation of the samples (Figs. 2, 6-8). This is strikingly illustrated by the almost twofold variation in REE abundances in the bergalites, which show only minor differences in major element composition (Figs. 2 and 9). The high REE contents of carbonatites (e.g., Loubet et al. 1972; Eby 1975) and the experimental data (Wendlandt and Harrison 1979) prove that REE are strongly fractionated into carbonate-rich fluids. Hence we conclude that the distribution of REE in the Nyiragongo magma column has been controlled to a large extent by a carbonated phase whose presence is still reflected in the high calcite content of the bergalites.

Our data support Sahama's view (Sahama $1973,1978)$ that the bergalites only represent the gas-laden, carbonated top of the Nyiragongo magma column. Their occurrence is therefore confined to the initial, explosive eruptive phases. The parent magma was only moderately enriched in volatiles, and it was closer in composition to the most undersaturated melilite-nephelinitic lavas $\left(\mathrm{SiO}_{2}=35-36 \% ; \mathrm{H}_{2} \mathrm{O}+\mathrm{CO}_{2}=2-\right.$ $4 \%)$.

Crystal fractionation in the Nyiragongo magma chamber or magma column has also been modelled with major element least-squares mass balance calculations, using the phenocryst compositions from Sahama (1978).

The calculations resolved two main fractionation stages. The first one applies to the differentiation of the bergalites and melilite-nephelinites. Compositional changes in the lavas are mainly

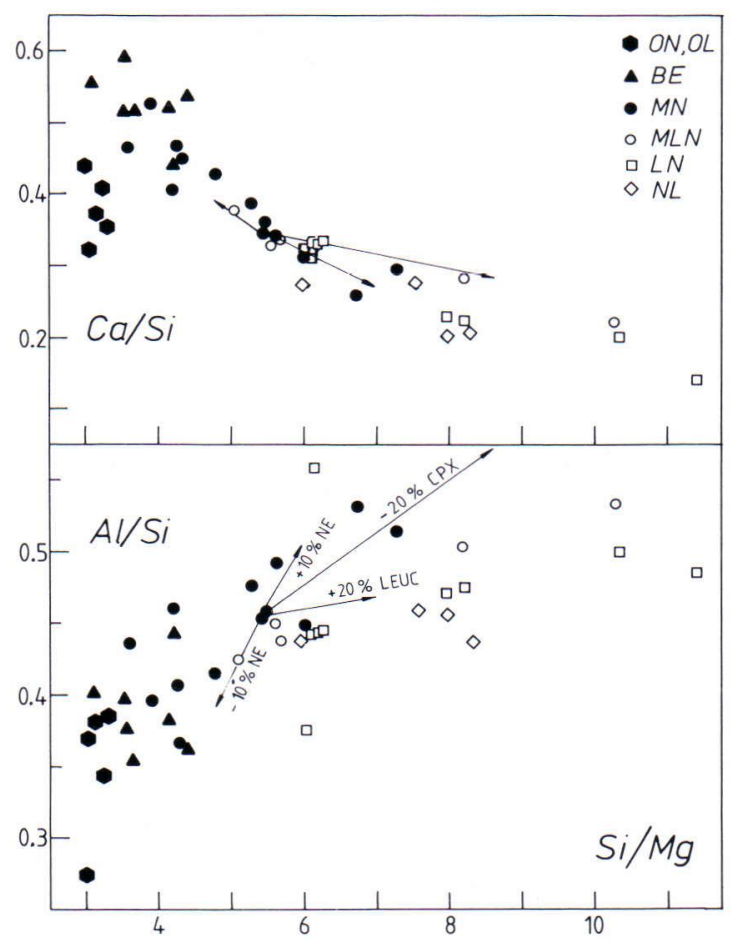

Fig. 9. Variation of atomic $\mathrm{Ca} / \mathrm{Si}, \mathrm{Al} / \mathrm{Si}$ and $\mathrm{Si} / \mathrm{Mg}$ ratios of the Nyiragongo lavas. Relative abundances of $\mathrm{Ca}, \mathrm{Al}$, $\mathrm{Mg}$ and $\mathrm{Si}$ are controlled by crystal fractionation involving melilite, clinopyroxene, nepheline and leucite. Melilite subtraction largely accounts for the decreasing $\mathrm{Ca} / \mathrm{Si}$ and increasing $\mathrm{Al} / \mathrm{Si}$ and $\mathrm{Si} / \mathrm{Mg}$ ratios of bergalites and melilitenephelinites. The superimposed fractionation vectors show the effect of clinopyroxene and nepheline subtraction (-) and nepheline and leucite flotation $(+)$ upon differentiation of melilite-nephelinites to leucite-nephelinites and nephelineleucitites. 
due to crystallization of melilite $(5-10 \%)$, olivine $(2-4 \%)$ and apatite $(2-3 \%)$. In addition, up to $5 \%$ of nepheline had to be either removed from or added (by flotation) to the melts to satisfy mass balance constraints. During this fractionation stage, the $\mathrm{SiO}_{2}$ content - recalculated to volatile free compositions - of the derivative magmas increased slightly (Fig. 2). The Ca/Si ratios decreased (Fig. 9) as a result of melilite fractionation, whereas the $\mathrm{Si} / \mathrm{Mg}$ ratio increased (Fig. 9) and the $\mathrm{Mg} /(\mathrm{Mg}+\mathrm{Fe}$ ) ratio decreased (Fig. 3) as a result of olivine fractionation. The increase in the $\mathrm{Al} / \mathrm{Si}$ ratio (Fig. 9) is largely accounted for by melilite and olivine crystallization, implying that nepheline fractionation was not generally important. The abundant nepheline phenocrysts apparently crystallized in situ and remained suspended in the melt owing to their relatively low density (ca. 2.66 $\left.\mathrm{g} / \mathrm{cm}^{3}\right)$.

The second fractionation stage applies to the melilite-leucite-nephelinites, leucite-nephelinites and nepheline-leucitites. Fractionating phases are clinopyroxene, Ti-rich magnetite, apatite, nepheline and leucite. The effect of clinopyroxene, nepheline and leucite fractionation during this stage is illustrated by fractionation vectors superimposed on Fig. 9. Flotation of low density leucite (ca. $2.47 \mathrm{~g} / \mathrm{cm}^{3}$ ) was rather important during this stage. Flotation of nepheline was required to model the compositions of the samples containing abundant rounded nepheline phenocryst aggregates (Sahama 1978). However, the scarcity of samples having $\mathrm{Al} / \mathrm{Si}$ ratios greater than 0.5 (Fig. 9) implies that the high modal abundance of nepheline in the "nephelineaggregate lavas', leucite-nephelinites and nepheline-leucitites is only partly due to crystal flotation.

Fractionation of clinopyroxene (up to $30 \%$ ) and magnetite (up to $8 \%$ ) turned out to be more important than the phenocryst abundances would suggest. In any case, the significant decrease in the $\mathrm{Mg} /(\mathrm{Mg}+\mathrm{Fe})$ ratio and Sc abundances (Fig. 3) requires removal of clinopyrox-
Table 4. Phenocryst/whole rock concentration ratios.

\begin{tabular}{lllcr}
\hline & CPX $^{1}$ & MEL $^{2}$ & NEPH $^{3}$ & LEUC $^{4}$ \\
\hline $\mathrm{Sc}$ & 9.2 & 0.03 & 0.02 & 0.007 \\
$\mathrm{Cr}$ & 1.8 & 0.02 & - & - \\
$\mathrm{Co}$ & 1.1 & 0.86 & 0.02 & 0.009 \\
$\mathrm{Ba}$ & 0.05 & 0.10 & 0.21 & 1.1 \\
$\mathrm{La}$ & 0.35 & 0.33 & 0.011 & 0.015 \\
$\mathrm{Ce}$ & 0.51 & 0.35 & 0.011 & 0.016 \\
$\mathrm{Nd}$ & 0.83 & 0.41 & 0.009 & 0.017 \\
$\mathrm{Sm}$ & 1.0 & 0.36 & 0.010 & 0.018 \\
$\mathrm{Eu}$ & 1.0 & 0.40 & 0.025 & 0.014 \\
$\mathrm{~Tb}$ & 1.1 & 0.28 & 0.023 & - \\
$\mathrm{Yb}$ & 0.94 & 0.095 & 0.023 & 0.018 \\
$\mathrm{Lu}$ & 1.0 & 0.082 & 0.028 & - \\
$\mathrm{Hf}$ & 2.8 & 0.10 & 0.046 & 0.07 \\
$\mathrm{Ta}$ & 0.25 & 0.001 & 0.025 & 0.01 \\
$\mathrm{Th}$ & 0.11 & 0.023 & 0.022 & 0.02 \\
$\mathrm{U}$ & 0.05 & 0.024 & 0.033 & 0.03 \\
\hline
\end{tabular}

1 Clinopyroxene from sample FEAE93, 2 Melilite from sample FEAE83, ${ }^{3}$ Nepheline from samples FEAE86 and FEAE88, normalized to whole rock data for FEAE89, ${ }^{4}$ Leucite from sample FEAE85.

ene. The increase in the $\mathrm{SiO}_{2}$ content (Fig. 2) during this fractionation stage is largely the result of leucite flotation and magnetite removal. The combined effect of clinopyroxene removal and leucite flotation is clearly reflected in the increasing $\mathrm{Si} / \mathrm{Mg}$ ratios, the decreasing $\mathrm{Ca} / \mathrm{Si}$ ratios and the levelling off of the $\mathrm{Al} / \mathrm{Si}$ ratios at a value of about 0.5 (Fig. 9).

Whereas the trace element abundances in the bergalites and melilite-nephelinites were mainly controlled by fluid fractionation, crystal fractionation was a more important process during the second differentiation stage. Melilite, clinopyroxene, nepheline and leucite mineral separates were analysed for trace elements to permit us to estimate crystal/liquid partition coefficients, (Table 4). Althought not analysed, apatite is known to have high partition coefficients ( $>$ 5) for all the REEs (Nagasawa 1970; Watson and Green 1981).

Nepheline and leucite partition coefficients are very low for all the elements measured except $\mathrm{Ba}$. Flotation of nepheline and leucite, together with removal of apatite, largely accounts 
for the generally lower concentrations of incompatible trace elements in the leucite-nephelinites and nepheline-leucitites (Figs. 4-6). Flotation of leucite is further reflected in the high $\mathrm{K}$ and $\mathrm{Ba}$ contents of leucite-rich lavas.

The REE partition coefficients for clinopyroxene are between 0.35 and 1.1, which are rather high values. With partition coefficients so close to unity, absolute REE abundances of derivative lavas should not vary much with the degree of clinopyroxene fractionation. However, extensive clinopyroxene fractionation appears to be responsible for the higher $\mathrm{La} / \mathrm{Yb}$ ratios (> 40; Fig. 6) of samples VM212, VM241 and S90, since these three samples also happen to have the lowest Sc contents, the lowest $\mathrm{Mg} /(\mathrm{Mg}+\mathrm{Fe})$ ratios (Fig. 3) and highest $\mathrm{Si} / \mathrm{Mg}$ ratios (they plot off scale in Fig. 9).

\section{Summary and concluding remarks}

From the low $\mathrm{Mg} / \mathrm{Fe}$ ratios and low $\mathrm{Sc}$ and $\mathrm{Cr}$ contents of the strongly undersaturated Nyiragongo nepheline-melilitites (bergalites) and melilite-nephelinites we infer that they derived from less undersaturated olivine-nephelinitic or basanitic (s.l.) mantle magmas by high-pressure ( $\geqslant 20$ kbar) pyroxene fractionation. Our data hence support earlier suggestions by Sahama (1978) and Pouclet $(1980 \mathrm{a}, \mathrm{b})$ that the adjacent Nyiragongo and Nyamuragira volcanoes ultimately evolved from very similar primary mantle magmas.

The main Nyiragongo lava types were formed by progressive low-pressure fractionation of a nepheline-melilititic (or melilite-nephelinitic) parent magma. Differentiation was dominated by melilite crystallization at the earlier stages. Later on, removal of clinopyroxene and flotation of leucite ( \pm nepheline) led to the formation of highly fractionated porphyritic leucitenephelinites and nepheline-leucitites.

The bergalites represent the volatile-enriched top of the melilititic magma column. Migrating carbonate-rich fluids affected strongly the distribution of incompatible trace elements. Fluid fractionation is most clearly reflected in the unusually large $\mathrm{Th} / \mathrm{U}$ fractionation and the high and variable REE abundances of the bergalites.

The essential aspects of Sahama's (1973, 1978) petrogenetic model for the Nyiragongo are corroborated by trace element data; he did not, however, apparently fully appreciate the importance of high- and low-pressure pyroxene fractionation.

Our data provide some constraints on the interpretation of the unusual $\mathrm{Pb}$ isotopic variations in the Nyiragongo lavas (Vollmer and Norry 1983), but we admit that the model presented here might need considerable revision once the causes of the $\mathrm{Pb}$ isotopic variations are fully understood.

Vollmer and Norry consider that the $\mathrm{Pb}$ isotopic variations are a feature inherited by the magmas from a heterogeneous mantle source. The source heterogeneity itself is presumed to be due to a ca. 500-Ma-old mantle metasomatic event. This interpretation can only be correct if (i) the seven samples analysed for $\mathrm{Pb}$ isotopes represent as many separate batches of mantle magmas; or if (ii) the radiogenic $\mathrm{Pb}$ was highly concentrated in an accessory mantle mineral that survived melting and failed to equilibrate with the melts (the interpretation preferred by Vollmer and Norry). The first assumption is within the realm of possibility, though it is rather surprising that every magma batch apparently experienced the same, somewhat complex fractionation history (Figs. 2-3). The second assumption does not seem to be very plausible, especially because the most radiogenic nepheline-leucitites and leucite-nephelinites are the end-products of a complex differentiation sequence and therefore had the least chance of retaining accessory mantle minerals.

Explanations in terms of contamination by old U-rich crystal phases should perhaps be reinstated. The evidence for extensive low-pres- 
sure fractionation undoubtedly implies that the Nyiragongo magmas have been trapped at crustal levels for extended periods. Whatever the case, solution of the Nyiragongo lead puzzle will have to await additional $\mathrm{Pb}$ isotopic analyses of well-documented samples. It would be of great interest to learn if $\mathrm{Pb}$ isotopic compositions correlate with rock type, and if there is a link between $\mathrm{Pb}$ isotopic variations and the large $\mathrm{Th} / \mathrm{U}$ fractionations reported in this paper.

Acknowledgements. We are greatly indebted to the late Professor Th. G. Sahama for providing samples and for stimulating discussions. This work was supported by grants from the Belgian Inter-University Institute for Nuclear Sciences (I.I.K.W.).

\section{References}

Bell, K. \& Bowell, J. L., 1969. Strontium isotopic studies of alkalic rocks: The potassium-rich lavas of the Birunga and Toro-Ankole regions, East and Central Equatorial Africa. Contrib. Mineral. Petrol., 10, 536-572.

Brey, G. \& Green, D. H., 1975. The role of $\mathrm{CO}_{2}$ in the genesis of olivine melilitite. Contrib. Mineral. Petrol. 49, 93-103.

— \& Green, D. H., 1977. Systematic study of liquidus phase relations in olivine melilitite $+\mathrm{H}_{2} \mathrm{O}+\mathrm{CO}_{2}$ at high pressures and petrogenesis of an olivine melilitite magma. Contrib. Mineral. Petrol. 61, 141-162.

Bultitude, R. J. \& Green, D. H., 1967. Experimental study at high pressures on the origin of olivine nephelinite and olivine melilite nephelinite magmas. Earth Planet. Sci. Lett. 3, 325-337.

Denaeyer, M. E., 1972. Les laves du fossé tectonique de l'Afrique Centrale (Kivu, Rwanda, Toro-Ankole). Ann. Mus. Roy. Afr. Centr. Belgique, Sér. IN-8, No. 72, pp. 134

-; Schellinck, F. \& Coppez, A., 1965. Recueil d'analyses des laves du fossé tectonique de l'Afrique Centrale. (Kivu, Rwanda, Toro-Ankole). Ann. Mus. Roy. Afr. Centr. Belgique, Sér. IN-8, Sci. géol., No. 49, pp. 234.

Eby, G. N., 1975. Abundance and distribution of the rareearth elements and yttrium in the rocks and minerals of the Oka carbonatite complex, Quebec. Geochim. Cosmochim. Acta 39, 597-620.

Edgar, A. D. \& Condliffe, E., 1978. Derivation of K-rich ultramafic magmas from a peridotitic mantle source. Nature 275, 639-640.

Frey, F. A.; Green, D. H. \& Roy, S. D., 1978. Integrated models of basalt petrogenesis: A study of quartz tholeiites to olivine melilitites from South Eastern Australia utilizing geochemical and experimental petrological data. J. Petrol. 19, 463-513.

Hertogen, J. \& Gijbels, R., 1971. Instrumental Neutron Activation Analysis of rocks with a low-energy photon detector. Anal. Chim. Acta 56, 61-82.

Holmes, A. \& Harwood, F., 1937. The petrology of the volcanic area of Bufumbira. Mem. geol. Surv. Uganda, 3 (2), pp. 300.

Irving, A. J., 1978. A review of experimental studies of crystal/liquid trace element partitioning. Geochim. Cosmochim. Acta 42, 743-770.

— \& Frey, F. A., 1978. Distribution of trace elements between garnet megacrysts and host volcanic liquids of kimberlitic to rhyolitic composition. Geochim. Cosmochim. Acta 42, 771-787.

Kampunzu, A. B.; Lubala, R. T.; Caron, J. P. H. \& Vellutini, P. J., 1983. Sur l'existence de deux cycles volcaniques précdent le volcanisme actuel des Virunga (Nord Kivu - Zäire). C. R. Acad. Sc. Paris, t. 296, Sér. II, $839-844$.

Langmuir, D., 1978. Uranium solution-mineral equilibria at low temperatures with applications to sedimentary ore deposits. Geochim. Cosmochim. Acta 42, 547-569.

Loubet, M.; Bernat, M.; Javoy, M. \& Allègre, C. J., 1972. Rare earth contents in carbonatites. Earth Planet. Sci. Lett. 14, 226-232.

Mitchell, R. H. \& Bell, K., 1976. Rare earth element geochemistry of potassic lavas from the Birunga and Toro-Ankole regions of Uganda, Africa. Contrib. Mineral. Petrol. 58, 293-303.

Nagasawa, H., 1970. Rare earth concentrations in zircons and apatites and their host dacites and granites. Earth Planet. Sci. Lett. 9, 359-364.

Pouclet, A., 1980 a. Les laves du rift de l'Afrique Centrale: Revue des données pétrographiques et chimiques; essai de magmatologie. Rapp. Ann. Mus. Roy. Afr. Centr. Belgique, Dépt. Géol. Min. 81-128.

Pouclet, A., 1980 b. Contribution à la systématique des lavas alcalins, les laves du rift de l'Afrique Centrale (Zä̈reUganda). Bull. Volcanol. 43-3, 527-540.

Pouclet, A.; Menot, R. P. \& Piboule, M., 1983. Le magmatisme alcalin potassique des Virunga (Rift Occidental de L'Afrique de l'Est). Une approche statistique dans la recherche des filiations magmatiques et des mécanismes de différenciation. Bull. Minéral. 106, 607-622. 
Sahama, Th. G., 1968. Mineralogical composition of the Nyiragongo rocks. Geol. Rundschau 57, 564-573.

,- 1973 . Evolution of the Nyiragongo magma. J. Petrol. $14,33-48$.

-, 1978. The Nyiragongo main cone. Ann. Mus. Roy. Afr. Centr. Belgique, Sér. IN-8, Sci. géol., No. 81, pp. 88 .

Smet, T., 1980. Radiochemische neutronenaktiveringsanalyse van gesteenten en gesteentevormende mineralen. Unpublished Ph.D. Thesis, Rijksuniversiteit Gent, Belgium, pp. 203.

Stormer, J. C. \& Nicholls, J., 1978. XLFRAC: A program for the interactive testing of magmatic differentiation models. Computers \& Geosciences 4, 143-159.

Tazieff, H., 1966. Etat actuel des connaissances sur le volcan Niragongo. Bull. Soc. géol. France 8, 176-200.

Vollmer, R. \& Norry, M. J., 1983. Unusual isotopic varia- tions in Nyiragongo nephelinites. Nature 301, 141-143.

Watson, E. B. \& Green, T. H., 1981. Apatite/liquid partition coefficients for the rare earth elements and strontium. Earth Planet. Sci. Lett. 56, 405-421.

Wendlandt, R. F. \& Harrison, W. J., 1979. Rare earth partitioning between immiscible carbonate and silicate liquids and $\mathrm{CO}_{2}$ vapor: Results and implications for the formation of light rare earth-enriched rocks. Contrib. Mineral. Petrol 69, 409-419.

Wood, D. A; Joron, J. L. \& Treuil, M., 1979. A reappraisal of the use of trace elements to classify and discriminate between magma series erupted in different tectonic settings. Earth Planet. Sci. Lett. 45, 326-336.

Wyllie, P. J., 1979. Magmas and volatile components. Am. Mineral. 64, 469-500. 